\title{
FORMULATION AND EVALUATION OF BILAYER TABLET OF CANDESARTAN AND HYDROCHLOROTHIAZIDE FOR THE TREATMENT OF HYPERTENSION
}

\author{
*Ankit Pateriya, Mithun Bhowmick, Girijesh Kumar Pandey, Amit joshi, Balkrishna Dubey
}

TIT College of Pharmacy, Bhopal, India

*Corresponding Author's E-mail: ankit_pateriya@yahoo.com, Contact No.:- +91-9685523140

\begin{abstract}
The main purpose of this study was to design bilayered sustained release tablet of Candesartan and Hydrochlorothiazide to provide renoprotection in hypertension. The bilayered tablet was prepared by using super disintegrant Cross Carmellose,starch sodium glycolate,crosspovidone for Hydrochlorothiazide to provide its immediate release and Candesartan was made sustained released by using HPMC K4,K15 polymer.lactose is used as diluents. The prepared different layer were characterized by different parameters like angle of repose, bulk density, tapped density, compressibility index, moisture content .The prepare d bilayered tablet was characterized by physical and chemical parameters such as tablet thickness, hardness, diameter, weight variation, drug content, friability and in vitro drug release. The present studies concluded that bilayered tablet of Candesar tan and Hydrochlorothiazide is novel approach to prevent hypertension.

Key words: Bilayered sustained release Tablet, Candesartan, Hydrochlorothiazide, Immediate release
\end{abstract}

\section{INTRODUCTION}

Some 600 million people worldwide have high blood pressure and nearly 3 million die every year as a direct result. Yet seven out of every 10 people with hypertension are not being treated adequately, according to WHO and the International Society of Hypertension (ISH). Combination drug therapy is recommended for patients whose blood pressure does not fall to optimal levels with single-drug treatment.

Bilayer tablet is new era for successful development of controlled release formulation along with various features to provide successful drug delivery system. Bilayer tablet is suitable for sequential release of two drugs in combination, separate two incompatible substances and also for sustained release tablet in which one layer is immediate release as loading dose and second layer is maintenance dose. The immediate release layer of bilayer tablet has worked as the loading dose and the sustained release layer has maintained therapeutic plasma drug concentration for prolonged time.

It is envisaged that the proposed work is designed as the Bilayer tablet of hydrochlorothiazide and candesartan. One layer of the bilayer tablet contains the hydrochlorothiazide as instant release, and the remaining second layer contains the canedesartan as control Layer. Hydrochlorothiazide is a thiazide diuretic that helps prevent your body from absorbing too much salt, which can cause fluid retention. Candesartan is an angiotensin II receptor antagonists. Candesartan keeps blood vessels from narrowing, which lowers blood pressure and improves blood flow. The combination of Hydrochlorothiazide and Candesartan is used to treat high blood pressure (hypertension).

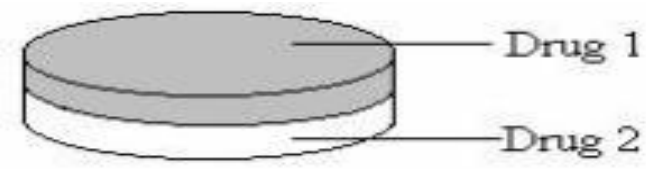

MATERIAL AND METHODS
Candesrtan and Hydrochlorothizide (Micro Lab. Hosur); HPMC K4 and K15 (Lobachem Pvt. Ltd., Mumbai); Sodium starch glycolate (Bioplus Life Science Banglore); Cross carmellose sodium, Microcrystaline cellulose and Lactose anhydrase (Merck Pvt, Ltd, Mumbai); Magnasium stearate, PVP K30 and Talc (S.D.Fine Chemical Ltd, Mumbai)

\section{Methods}

\section{Preformulation}

Physiochemical Properties of candesartan and hydrochlorothiazide

\section{A) Organoleptic evaluation}

It refers to the evaluation by sensory characters-taste, appearance, odor, feel of the drug, etc.

\section{B) Solubility (at room temp: )}

We will check the solubility of both of drugs in water, hot water, $0.1 \mathrm{~N} \mathrm{HCL}, 0.1 \mathrm{NaOH}$, acetone, ethanol, chloroform, methanol at room temperature.

\section{C) Identification Test}

\section{FTIR Spectroscopy}

Infra- red spectrum is an important record which gives sufficient information about the structure of a compound. This technique provides a spectrum containing a large number of absorption band from which a wealth of information can be derived about the structure of an organic compound.

D) Loss on drying: Loss on drying directly measuring by IR moisture balance. Firstly calibrate the instrument by knob then take 5.000 gm sample (powder) and set the temp at $100^{\circ} \mathrm{C}$ to $105^{\circ} \mathrm{C}$ for 5 minutes and constant reading set the knob and check \% moisture.

E) Determination of $\mathrm{pH}(1 \mathrm{w} / \mathrm{v}$ solution in water): 
$1 \mathrm{gm}$ of the Powder was taken and dissolved in $100 \mathrm{ml}$ of distilled water with sonication and filtered, $\mathrm{pH}$ of the filtrate was checked with standard glass electrode.

\section{F) Melting point:}

It is one of the parameters to judge the purity of drugs. In case of pure chemicals, melting points are very sharp and constant. Since the drugs contain the mixed chemicals, they are described with certain range of melting point. A small quantity of powder was placed into a fusion tube. That tube is placed in the melting point determining apparatus containing castor oil. The temperature of the castor oil was gradual increased automatically and read the temperature at which powder started to melt and the temperature when all the powder gets melted.

\section{G) Bulk properties}

A known quantity of powder was poured into the measuring cylinder carefully level the powder without compacting, if necessary and read the unsettled apparent volume, Vo, to the nearest graduated unit. Calculate the bulk density, in gm per $\mathrm{ml} \mathrm{gm} / \mathrm{cc}$, by the formula

$$
\text { Bulk density = Bulk Mass/ Bulk Volume }
$$

\section{H) Compressibility index (Carr's index)}

Compressibility index (C.I.) is an important measure that can be obtained from the bulk and tapped densities. Carr's index a material having values of less than $20 \%$ to $30 \%$ is defined as the free flowing material. Shown in Table 1.

It can be calculated as per given formula:

$$
\text { C.I }=\frac{\text { Tapped density- Bulk density }}{\text { Tapped density }} * 100
$$

Table 1: Carr's index range

\begin{tabular}{|c|c|c|}
\hline S. no. & \% Comp. Index & Properties \\
\hline 1 & $5-12$ & Excellent \\
\hline 2 & $12-16$ & Good \\
\hline 3 & $18-21$ & Fair - passable \\
\hline 4 & $23-25$ & Poor \\
\hline 5 & $33-38$ & Very Poor \\
\hline 6 & $>40$ & Extremely poor \\
\hline
\end{tabular}

\section{I) Hausner ratio:}

It indicates the flow properties of the powder and is measured by the ratio of tapped density to bulk density. Shown in Table 2.

Hausner ratio $=$ Tapped density $/$ Bulk Density

Table 2: Hausner ratio and flow property characteristics

\begin{tabular}{|c|c|c|}
\hline S. no. & Hausner ratio & Property \\
\hline 1. & $0.0-1.2$ & Free flowing \\
\hline 2. & $1.2-1.6$ & Cohesive powder \\
\hline
\end{tabular}

Standard value of Hausner ratio is 1.25.

J) Angle of repose:

두 2011, JDDT. All Rights Reserved
The angle of repose is a relatively simple technique for estimating the flowability of a powder through a funnel and fall freely onto a surface. The height and diameter of the resulting cone is measured and using the following equation, the angle of repose can be calculated.

$$
\operatorname{Tan} \theta=\mathbf{h} / \mathbf{r}
$$

Where $h, r$ is the relatively height and radius of the powder cone.

For most pharmaceutical powders, the angle of repose values range form 25 to 45 , with lower values indicating better flow characteristics. Values of angle of repose $\leq 30$ usually indicate a free flowing material and angle $\geq 40$ suggest a poorly flowing material.

\section{k) MOISTURE CONTENT DETERMINATION}

Principle: The titrimetric determination of water is based upon the quantitative reaction of water with an anhydrous solution of sulphur dioxide and iodine in the presence of a buffer that reacts with hydrogen ions. In the original titrimetric solution, known as Karl Fisher Reagents, the sulfur dioxide and iodine was dissolved in pyridine and methanol. The test specimen may be titrated with the reagent directly, or the analysis may be carried out by a residual titration procedure. The stoichiometry of the reaction is not exact, and the reproducibility of a determination depends upon such factors as the relative concentration of the reagent ingredients, the nature of the inert solvent used to dissolve the test specimen, and the technique used in the particular determination. Therefore, an empirically standardized technique is used in order to achieve the desired accuracy. Precision in the method is governed largely by the extent to which atmospheric moisture is excluded from the system. The titration of water is usually carried out with the use of anhydrous methanol as the solvent for the test specimen; however other suitable solvents may be used for special or unusual test specimens. (Note: Now-a-days pyridine free KF reagents are coming in which pyridine is replaced by the imidazole, because pyridine has carcinogenic effects).

\section{L) DETERMINATION OF $\boldsymbol{\lambda}$ max. OF CANDESARTAN}

Accurately weighed $10 \mathrm{mg}$ of drug was dissolved in $10 \mathrm{ml}$ of $6.8 \mathrm{PH}$ buffer solution in $10 \mathrm{ml}$ of volumetric flask.the resulted solution $1000 \mu \mathrm{g} / \mathrm{ml}$ and from this solution $1 \mathrm{ml}$ pippet out and transfer into $10 \mathrm{ml}$ volumetric flask and volume make up with $6.8 \mathrm{PH}$ buffer solution prepare suitable dilution to make it to a concentration range of 5$25 \mu \mathrm{g} / \mathrm{ml}$. The spectrum of this solution was run in 200$400 \mathrm{~nm}$ range in U.V spectrophotometer (Labindia3000+). The Candesartan shows the absorbance maxima at $257 \mathrm{~nm}$ in $6.8 \mathrm{PH}$ buffer solution.

\section{M) DETERMINATION OF $\lambda \quad \max$ OF} HYDROCHLOROTHIAZIDE

Accurately weighed $10 \mathrm{mg}$ of drug was dissolved in $10 \mathrm{ml}$ of 6.8 PH buffer solution (methanol used as cosolvent) in $10 \mathrm{ml}$ of volumetric flask. The resulted solution $1000 \mu \mathrm{g} / \mathrm{ml}$ and from this solution $1 \mathrm{ml}$ pippet out and transfer into $10 \mathrm{ml}$ volumetric flask and volume make up with $6.8 \mathrm{PH}$ buffer solution prepare suitable dilution to make it to a concentration range of $5-25 \mu \mathrm{g} / \mathrm{ml}$. The spectrum of this solution was run in $200-400 \mathrm{~nm}$ range in U.V spectrophotometer (Labindia-3000+). The 
Hydrochlorothiazide shows the absorbance maxima at 272 $\mathrm{nm}$ in $6.8 \mathrm{PH}$ buffer solutions.

\section{PHASE-I PREPRATION OF INSTANT LAYER OF HYDROCHLOROTHIAZIDE}

Fast dissolving tablets of Hydrochlorothiazide were prepared by direct compression method after incorporating different superdisintegrants such as, crosscarmellose sodium (Ac-Di-Sol), crospovidone and sodium starch glycolate in different concentrations. The above ingredients was weighed and mixed in geometric progression in a dry and clean mortar. Then the ingredients were passed through mesh \#60.
Magnesium stearate as lubricant and talc as glidant were added in a final step and mixed, this blend was subjected to analysis of pre-compression parameters which included Angle of repose, Bulk density, Tap density, Carr's index and Hausner's ratio.

The Blend was compressed on $8 \mathrm{~mm}$ (diameter) fat punches on a 'Rimek mini press 16 station rotary compression machine. Eight formulations of Hydrochlorothiazide granules were prepared and each formulation contained one of the three disintegrant in different concentration. Each tablets weighing $100 \mathrm{mg}$, were obtained. Composition of tablets is mentioned in Table 3.

Table 3: Composition of Hydrochlorothiazide Fast Dissolving Tablets

\begin{tabular}{|l|c|c|c|c|c|c|c|c|c|}
\hline \multirow{2}{*}{ Ingredients(mg) } & \multicolumn{9}{|c|}{ Formulation code } \\
\cline { 2 - 21 } & TM1 & TM2 & TM3 & TM4 & TM5 & TM6 & TM7 & TM8 & TM9 \\
\hline Hydrochlorothiazide & 25 & 25 & 25 & 25 & 25 & 25 & 25 & 25 & 25 \\
\hline $\begin{array}{l}\text { Sodium } \\
\text { Starch glycolate }\end{array}$ & 4 & 6 & 8 & - & - & - & - & - & - \\
\hline Croscarmellose odium & - & - & - & 4 & 6 & 8 & - & - & - \\
\hline Crospovidone & - & - & - & - & - & - & 4 & 6 & 65 \\
\hline $\begin{array}{l}\text { Microcrystalline } \\
\text { cellulose }\end{array}$ & 65 & 65 & 65 & 65 & 65 & 65 & 65 & 65 & 04 \\
\hline Magnesium stearate & 06 & 04 & 02 & 06 & 04 & 02 & 06 & 04 & 02 \\
\hline Total weight & 100 & 100 & 100 & 100 & 100 & 100 & 100 & 100 & 100 \\
\hline
\end{tabular}

\section{EVALUATION OF POSTCOMPRESSION PARAMETER}

\section{Shape and colour of tablets:}

Uncoated tablets were examined under a lens for the shape of the tablet and colour was observed by keeping the tablets in light.

\section{- Thickness test}

Three tablets were picked from each formulation randomly and thickness was measured individually. It is expressed in $\mathrm{mm}$ and standard deviation was also calculated. The tablet thickness was measured using dial-caliper (Mitutoyo, Japan).

\section{- Weight variation test}

Twenty tablets were selected randomly from each formulation and average weight was determined. The tablets were weighed individually and compared with average weight. The U.S Pharmacopoeia allows a little variation in the weight of a tablet. The following percentage deviation in weight variation is allowed (Table No.6.7).

Table 4: Percentage deviation in weight variation

\begin{tabular}{|c|c|c|}
\hline S. NO. & Average Weight of A Tablet & Percentage Deviation \\
\hline 1. & $130 \mathrm{mg}$ or less & 10 \\
\hline 2. & More than $130 \mathrm{mg}$ and less than $324 \mathrm{mg}$ & 7.5 \\
\hline 3. & $324 \mathrm{mg}$ or more & 5 \\
\hline
\end{tabular}

In all the formulations the tablets weight is more than 130 $\mathrm{mg}$ and less than $324 \mathrm{mg}$, hence $7.5 \%$ maximum difference allowed.

\section{- Hardness test}

The hardness of tablet was measured by Pfizer hardness tester and results were expressed in $\mathrm{Kg} / \mathrm{cm}^{2}$.

\section{- Friability test}

For this, 20 tablets were taken from each formulation and the friability was determined using Roche friabilator. The equipment was run for $4 \mathrm{~min}$ at 25 revolutions per minute. The tablets were taken out, dedusted and reweighted and
$\%$ friability was calculated. The friability was determined as the mass loss in percent according to Equation:-

$$
\% \text { Friability }=(\text { Loss in weight } / \text { Initial weight }) \times 100
$$

The test complies if tablets not lose more than $1 \%$ of their weight

\section{- Uniformity of drug content:}

The test is mandatory for tablets with $10 \mathrm{mg}$ or less weight of active ingredient. Ten randomly selected tablets from each formulation ( $\mathrm{F} 1$ to $\mathrm{F} 9$ ) were finely powdered and Drug equivalent to $10 \mathrm{mg}$ of drug dissolved in $10 \mathrm{ml} 0.1$ $\mathrm{N} \mathrm{HCl}$ (simulated gastric fluid of $\mathrm{pH} 1.2$ without 
enzymes) sonicate it for 20 minutes, till the entire drug leached out from complex, then the solution was filtered through whatman filter paper No. 41. From this Solution take $1 \mathrm{ml}$ and Diluted up to $100 \mathrm{ml}$ with $0.1 \mathrm{~N}$ $\mathrm{HCl}$ and the drug content was determined spectrophotometrically at $272.0 \mathrm{~nm}$.

\section{PREPRATION OF CANDESARTAN MATRIX TABLET}

Direct compression was followed to manufacture the gas generating floating tablets of simvastatin. All the polymers selected, drug and excipients were passed through sieve no. 40 before using into formulation. Polymers selected for tablets are HPMC K15, HPMC K4, PVP-K30. Excipients like Lactose anhydrous,Talc, Magnesium Stearate were selected for the study.

\section{Steps involved in the manufacture of tablets}

- First the drug, polymer and other excipients selected were passed through 40- mesh sieve. Required quantity of drug, polymer and excipients were weighed properly and transferred into polyethylene bag and the blend was mixed for at least $15 \mathrm{~min}$.

The blend obtained was then lubricated by adding $1 \%$ magnesium stearate and again mixed for another $5 \mathrm{~min}$.

Table 5: Various formulation of Candesartan Matrix tablet

\begin{tabular}{|c|c|c|c|c|c|c|c|c|c|}
\hline Excipients & F1 & F2 & F3 & F4 & F5 & F6 & F7 & F8 & F9 \\
\hline Candesartan & 32 & 32 & 32 & 32 & 32 & 32 & 32 & 32 & 32 \\
\hline HPMC K 4 & 130 & 120 & 110 & - & - & - & 65 & 60 & 55 \\
\hline HPMC K 15 & - & - & - & 130 & 120 & 110 & 65 & 60 & 55 \\
\hline Lactose anhydrous & 18 & 28 & 38 & 18 & 28 & 38 & 18 & 28 & 38 \\
\hline PVP-k30 & 16 & 16 & 16 & 16 & 16 & 16 & 16 & 16 & 16 \\
\hline Talc & 2 & 2 & 2 & 2 & 2 & 2 & 2 & 2 & 2 \\
\hline Magnesium stearate & 2 & 2 & 2 & 2 & 2 & 2 & 2 & 2 & 2 \\
\hline Total & 200 & 200 & 200 & 200 & 200 & 200 & 200 & 200 & 200 \\
\hline
\end{tabular}

\section{EVALUATION OF MATRIX TABLET}

All the tablets were evaluated for following different parameters which includes;

\section{General Appearance}

Five tablets from different batches were randomly selected and organoleptic properties such as color, odor, taste, shape, were evaluated. Appearance was judged visually.

Very good $(+++)$, good $(++)$, fair $(+)$ poor $(-)$, very poor $(-$ $-)$.

\section{Thickness and diameter}

Thickness and diameter of tablets were determined using Vernier caliper. Five tablets from each batch were used, and an average value was calculated.

\section{Hardness}

For each formulation, the hardness of five tablets was determined using the Monsanto hardness tester (Cadmach).

\section{Friability}

The friability of a sample of 10 tablets was measured using a Friability tester (Electro Lab). Ten tablets were weighed, rotated at $25 \mathrm{rpm}$ for 4 minutes. Tablets were reweighed after removal of fines (dedusted) and the percentage of weight loss was calculated.

\section{Uniformity of weight}

Twenty tablets were randomly selected from each batch individually weighed, the average weight and standard deviation of 20 tablets was calculated.

\section{Drug content}

Twenty tablets were taken and amount of drug present in each tablet was determined. The tablets were crushed in a mortar and the powder equivalent to $100 \mathrm{mg}$ of drug was transferred to $100 \mathrm{ml}$ standard flask. The powder was dissolved in $50 \mathrm{ml}$ of $\mathrm{pH} 6.8$ Phosphate Buffer and made up to volume with buffer. The sample was mixed thoroughly and filtered through a $0.45 \mu$ membrane filter. The filtered solution was diluted suitably and analyzed for drug content by UV spectrophotometer at a $\lambda$ max of 257.0 nm using of pH 6.8 Phosphate Buffer as blank.

\section{- Dissolution rate studies}

In vitro drug release of the sample was carried out using USP- type II dissolution apparatus (Paddle type). The dissolution medium, $900 \mathrm{ml} \mathrm{pH} 6.8$ Phosphate Buffer (Tween 20, 0.1\%) was placed into the dissolution flask maintaining the temperature of $37 \pm 0.50 \mathrm{c}$ and $\mathrm{rpm}$ of 50 . One Candesartan Control layer tablet was placed in each basket of dissolution apparatus. The apparatus was allowed to run for 12 hours. Sample measuring $4 \mathrm{ml}$ were withdrawn after $30 \mathrm{~min} ., 1.0 \mathrm{hr}, 1.30 \mathrm{hr}, 2.0 \mathrm{hr}, 3 \mathrm{hr} ., 4.0$ $\mathrm{hr}, 6.0 \mathrm{hr}, 8.0 \mathrm{hr} 10.0 \mathrm{hr}, 12$ hour using $4 \mathrm{ml}$ pipette. The fresh dissolution medium was replaced every time with the same quantity of the sample.

\section{FORMULATION OF BILAYER TABLETS}

Optmized bach of Instant Layer (TM4) and Optmized bach of Sustain layer(F7) used to formulate Bilayer tablet of Hydrochlorothiazide and Candesartan. Procedure of formulation same as method as previous.

All the tablets were evaluated for following different parameters which includes;

\section{General Appearance}

Five tablets from different batches were randomly selected and organoleptic properties such as color, odor, taste, shape, were evaluated. Appearance was judged visually.

Very good $(+++)$, good $(++)$, fair $(+)$ poor $(-)$, very poor $(-$ $-)$. 


\section{Thickness and diameter}

Thickness and diameter of tablets were determined using Vernier caliper. Five tablets from each batch were used, and an average value was calculated.

\section{Hardness}

For each formulation, the hardness of five tablets was determined using the Monsanto hardness tester (Cadmach).

\section{Friability}

The friability of a sample of 10 tablets was measured using a Friability tester (Electro Lab). Ten tablets were weighed, rotated at $25 \mathrm{rpm}$ for 4 minutes. Tablets were reweighed after removal of fines (dedusted) and the percentage of weight loss was calculated.

\section{Uniformity of weight}

Twenty tablets were randomly selected from each batch individually weighed, the average weight and standard deviation of 20 tablets was calculated.

\section{Drug content}

Twenty tablets were taken and amount of drug present in each tablet was determined. The tablets were crushed in a mortar and the powder equivalent to $32 \mathrm{mg}$ of Candesartan was transferred to $100 \mathrm{ml}$ standard flask. The powder was dissolved in $50 \mathrm{ml}$ of methanol and made up to volume with methanol. The sample was mixed thoroughly and filtered through a $0.45 \mu$ membrane filter. The filtered solution was further diluted $1 \mathrm{ml}$ to $10 \mathrm{ml}$ suitably (32 ppm of candesartan and $25 \mathrm{ppm}$ of Hydrochlorothiazide) and Determine the Conc. of both drugs using Simultaneous estimation method

\section{Dissolution rate studies}

In vitro drug release was performed according to the USP dissolution apparatus II at $50 \mathrm{rpm}$ and $37 \pm 0.5^{\circ} \mathrm{C}$ temperature over a $12 \mathrm{hrs}$ period for Candesartan SR and 2 hr for Hydrochlorothiazide IR, using an automated paddle dissolution system (Labindia). A minimum of 6 tablets per batch were tested.

The media used was $0.1 \mathrm{~N} \mathrm{HCl}$ at a $\mathrm{pH} 1.2$ and a volume of $900 \mathrm{ml}$ for the first 2 hours after and then $\mathrm{pH}$ of 6.8 and maintained at $37+0.5^{\circ} \mathrm{C}$ upto 12 Hours. Test sample $(4 \mathrm{ml})$ was withdrawn at particular time interval and replaced with fresh dissolution media maintained at the same temperature and the concentration of dissolved drug was determined using U.V. (Ultraviolet Labindia 3000+) spectrophotometer at $\lambda \max 257 \mathrm{~nm}$ for Candesartan and $272.0 \mathrm{~nm}$ for Hydrochlorothiazide.

\section{RESULTS AND OBSERVATION}

PREFORMULATION

\section{PHYSICO-CHEMICAL PROPERTIES OF CANDESARTAN AND HYDRO}

\section{-CHLOROTHIAZIDE}

\section{A). Organoleptic evaluation:}

Table 6: Organoleptic property of Candesartan

\begin{tabular}{|c|c|}
\hline Color & white \\
\hline Odor & characteristic \\
\hline
\end{tabular}

Table 7: Organoleptic property of Hydrochlorothiazide

\begin{tabular}{|l|l|}
\hline Color & White \\
\hline Odor & Characteristic \\
\hline
\end{tabular}

\section{B) Solubility:}

Solubility study of Candesartan and hydrochlorothiazide has been done in various solvent such as water, Phosphate buffer $\mathrm{pH}$ 6.8, Phosphate buffer $\mathrm{pH} 7.4$ and $0.1 \mathrm{~N} \mathrm{HCl}$ solution. We were found that a solubility of candesartan and hydrochlorothiazide were slightly soluble in a $0.1 \mathrm{~N}$ $\mathrm{HCl}$ solution.

Table 8: Solubility in various solvent

\begin{tabular}{|c|c|c|c|}
\hline S. No. & Solvent & Candesartan & Hydrochlorothiazide \\
\hline 1 & Water & In soluble & In soluble \\
\hline 2 & Ethanol & Freely soluble & Soluble \\
\hline 3 & Methanol & Freely soluble & Soluble \\
\hline 4 & Acetone & Freely soluble & Soluble \\
\hline 5 & $0.1 \mathrm{~N} \mathrm{HCl}$ & Slightly soluble & Slightly soluble \\
\hline 6 & $6.8 \mathrm{pH}$ buffer & Soluble & Soluble \\
\hline 7 & $7.4 \mathrm{pH}$ buffer & Soluble & Soluble \\
\hline
\end{tabular}

\section{C) Identification test by FTIR:}

Identification of Candesartan and Hydrochlorothiazide by FTIR Spectroscopy with respect to marker compound

Candesartan and Hydrochlorothiazide was obtained as White or almost white crystalline powder. It was identified from the result of IR spectrum as per specification.

\section{Sample of pure Candesartan and Hydrochlorothiazide}

The IR spectrum of sample drug shows the peak values which are characteristics of the drug and the graph was shown in figure no. 7.1 and 7.2. 


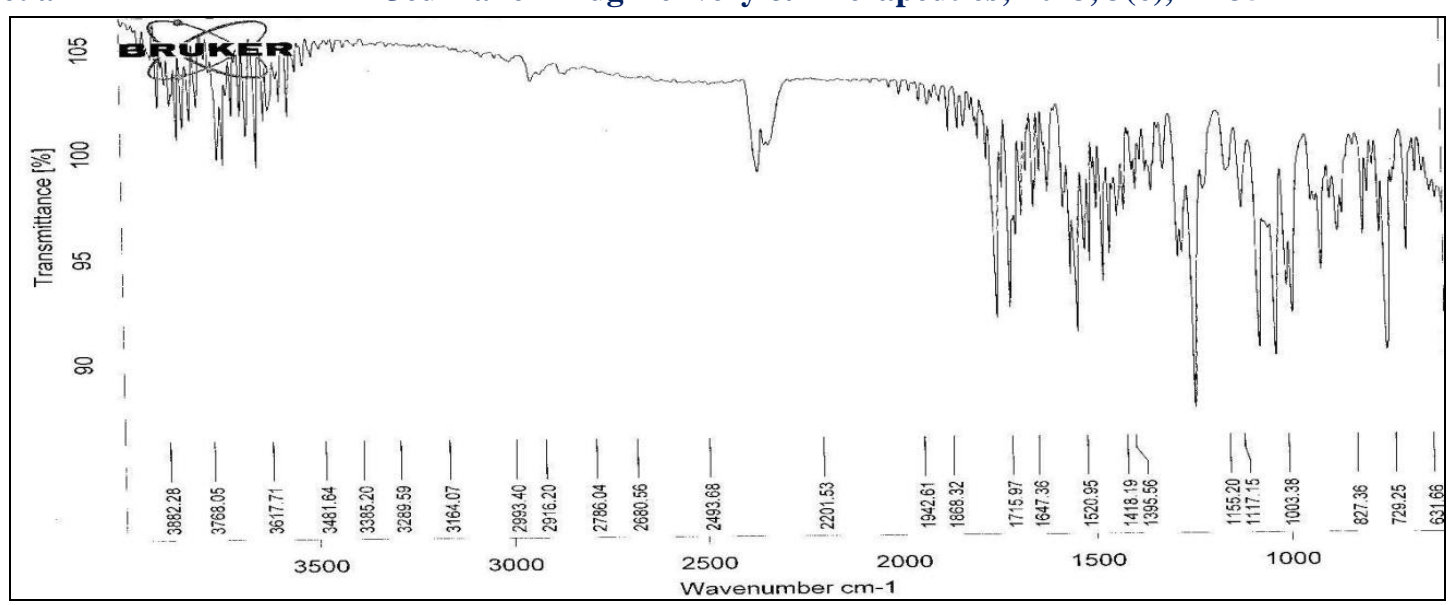

Figure 1: FT-IR Spectrum of Pure Drug (Candesartan) zide)

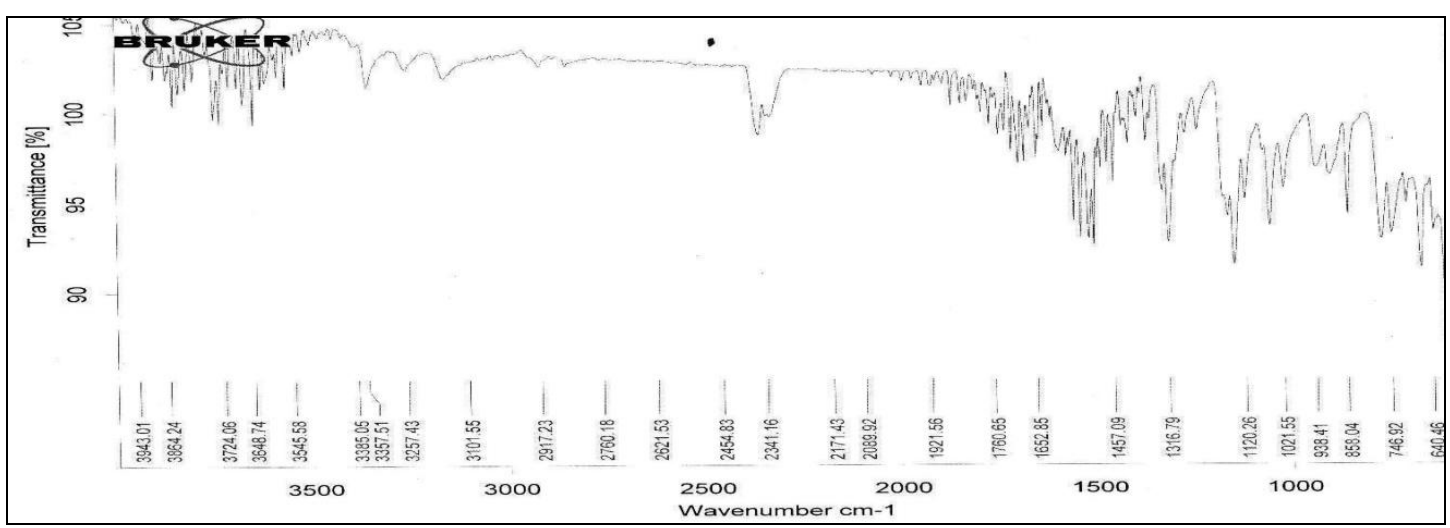

Figure 2: FT-IR Spectrum of Pure Drug (Hydrochlorothia

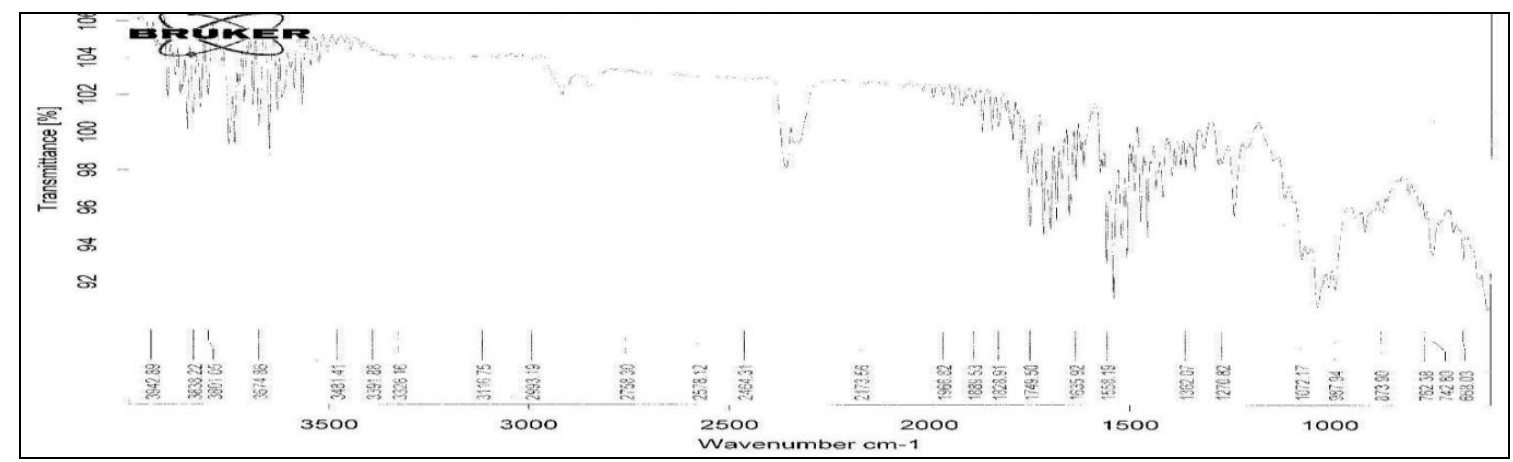

Figure 3: FT-IR Spectrum of Candesartan and excipients

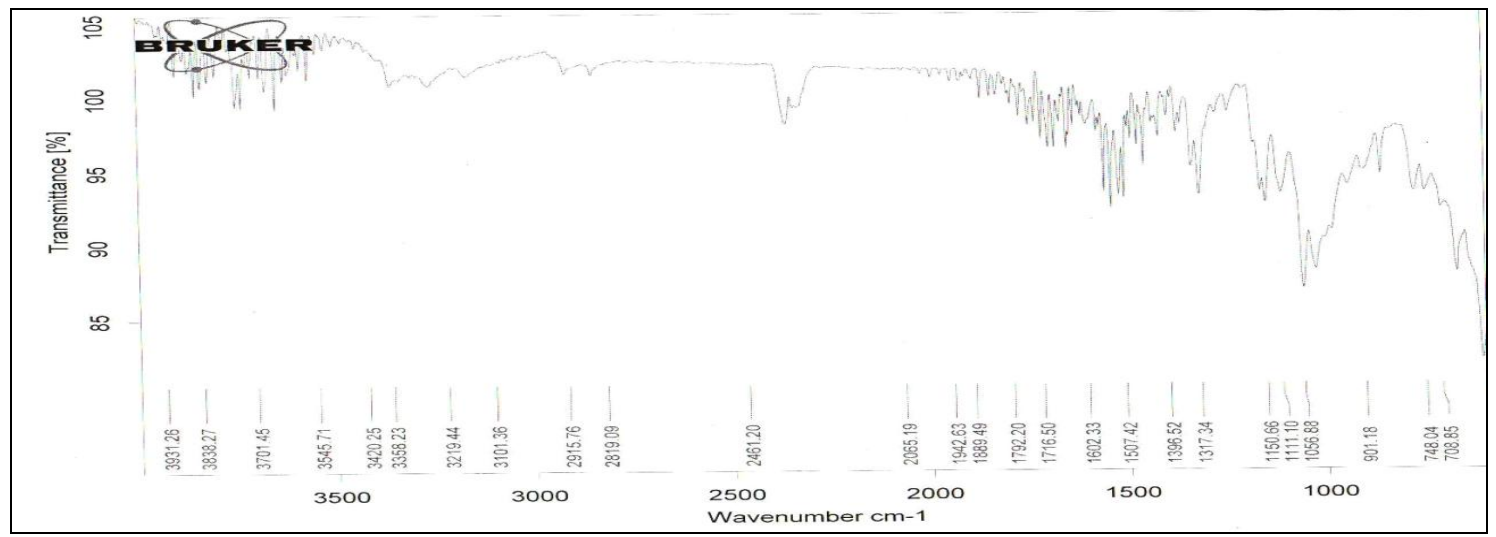

Figure 4: FT-IR Spectrum of Hydrochlorothiazide and Excipients 


\section{E) Loss on Drying (LOD):}

Procedure: Loss on drying directly measuring by IR moisture balance. Firstly calibrate the instrument by knob then take $1.000 \mathrm{gm}$ sample (powder) and set the temp at $100^{\circ} \mathrm{C}$ to $105^{\circ} \mathrm{C}$ for 5 minutes and constant reading set the knob and check $\%$ moisture.

Result: The percentage of loss on drying of Candesartan and hydrochlorothiazide $\mathbf{0 . 0 2 0} \%$ w/w and $\mathbf{0 . 0 2 5 5} \%$ w/w.

F) Determination of $\mathrm{pH}(1 \mathrm{w} / \mathrm{v}$ solution in water $)$ :

The $\mathrm{pH}$ determination of Candesartan and Hydrochlorothiazide was done by Digital $\mathrm{pH}$ meter and found to be 6.4 and.4.43.

\section{G) Melting Point:}

Procedure: A small quantity of powder was placed into a fusion tube. That tube is placed in the melting point determining apparatus containing castor oil. The temperature of the castor oil was gradually increased automatically and read the temperature at which powder started to melt and the temperature noted when all the powder gets melted.

Result: Melting point of Candesartan and Hydrochlorothiazide determine by Melting point apparatus at $157-160^{\circ} \mathrm{C}$ and $265-280^{\circ} \mathrm{C}$.

H) Flow Property of Candesartan and Hydrochlorothiazide Powder:

- Bulk density:

A known quantity of powder was poured into the measuring cylinder carefully level the powder with out compacting, if necessary and read the unsettled apparent volume, $\mathrm{V}_{\mathrm{o}}$, to the nearest graduated unit. Calculate the bulk density, in $\mathrm{gm} / \mathrm{ml}$ $\mathrm{gm} / \mathrm{cc}$, by the formula.

Bulk density = Bulk Mass/ Bulk Volume

Table 9: Bulk Density of Candesartan and Hydrochlorothiazide

\begin{tabular}{|l|l|l|l|}
\hline S. No. & Density & Candesartan & Hydrochlorothiazide \\
\hline 1 & Untapped density & $0.22 \mathrm{~g} / \mathrm{cc}$ & $0.4 \mathrm{~g} / \mathrm{cc}$ \\
\hline 2 & Tapped density(after 50 tapping) & $0.40 \mathrm{~g} / \mathrm{cc}$ & $0.71 \mathrm{~g} / \mathrm{cc}$ \\
\hline
\end{tabular}

- Compressibility Index (\%)

$$
\begin{gathered}
\mathrm{C.I}=\frac{100\left(\mathrm{~V}_{0}-\mathrm{V}_{\mathrm{f}}\right)}{\mathrm{V}_{0}} \quad \mathrm{OR} \\
\mathrm{C.I}=\frac{\text { Tapped density- Bulk density }}{\text { Tapped density }} * 100
\end{gathered}
$$

Result: The compressibility index of Candesartan and hydrochlorothiazide respectively is $45 \%$ and $44.2 \%$.

\section{- Hausner ration:}

\section{Hausner Ratio = Tapped density / Bulk Density}

Result: The Hausner ration of candisaratn and hydrochlorothiazide respectively is $\mathbf{1 . 8 1 8}$ and 1.77.

\section{- Angle of Repose}

Procedure: The angle of repose is a relatively simple technique for estimating the flowability of a powder through a funnel and fall freely onto a surface. The height and diameter of the resulting cone is measured and using the following equation, the angle of repose can be calculated. Weigh $10 \mathrm{gm}$ of drug (Candesartan and Hydrochlorothiazide) powder accurately, and pass through the fennel height up to $2.5 \mathrm{~cm}$ from surface and measure the height and diameter by scale.

$\operatorname{Tan} \theta=\mathrm{h} / \mathrm{r}$

Where $h, r$ is the relatively height and radius of the powder cone.

Result: The Angle of repose of Candesartan and hydrochlorothiazide $38.0 \& 37.0$ degree respectively.

\section{I) Moisture by Karl-Fischer Apparatus (KF)}

Result: The Moisture content of Candesartan and hydrochlorothiazide is 0.1095 and $0.073 \%$ respectively.

\subsubsection{DETERMINATION OF $\lambda_{\text {MAX }}$ BY UV-VISIBLE SPECTROSCOPY}

Standard solution $(10 \mathrm{~g} / \mathrm{ml})$ of pure Candesartan and Hydrochlorothiazide was prepared. The pure drug solutions were scanned on UV spectrophotometer, which showed maximum absorbance at 257.0nm and 272.0nm for Candesartan and hydrochlorothiazide respectively.

- Determination of $\lambda \max$ of Candesartan

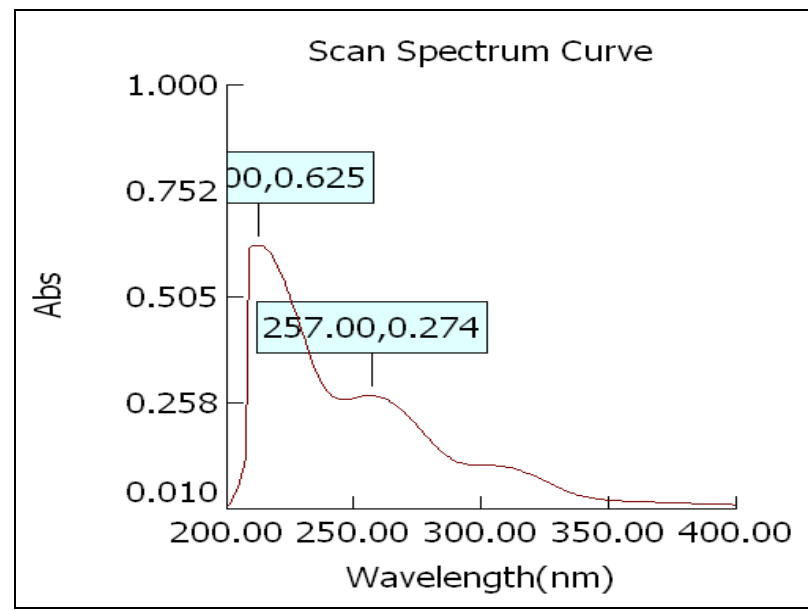

Figure 5: Determination of $\lambda \max$ of Candesartan at 257.0nm

Result: Partical size pass through 40\# is $\mathbf{1 0 0}$ (\%w/w). 


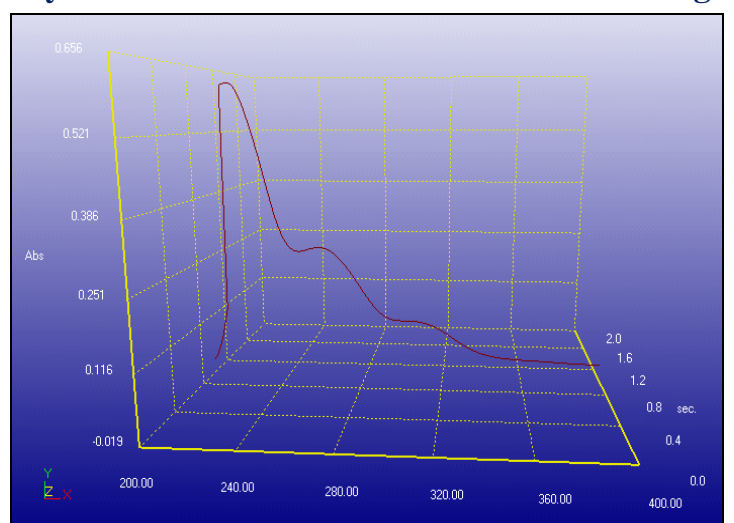

Figure 6: 3D Spectrum of Determination of $\lambda \max$ of Candesartan at $257.0 \mathrm{~nm}$

\section{- Determination of $\lambda \max$ of Hydrochlorothiazide}

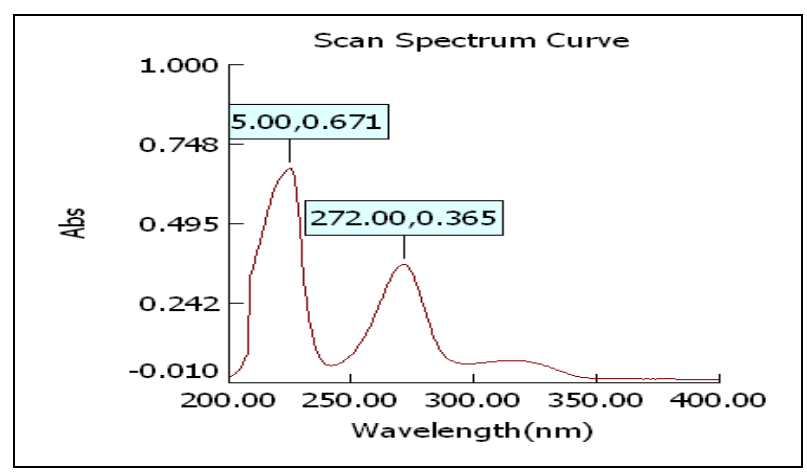

Figure: 7 Determination of $\lambda \max$ of Hydrochlorothiazide at $272.0 \mathrm{~nm}$

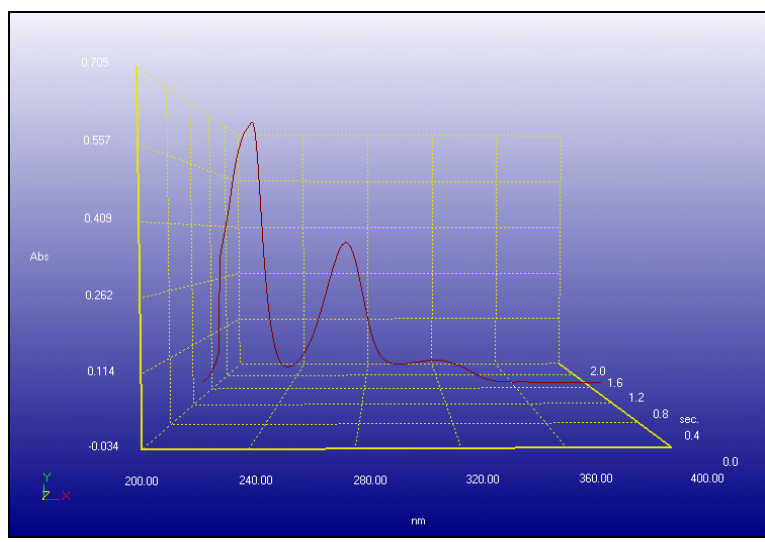

Figure 8: 3D Spectrum of Determination of $\lambda \max$ of Hydrochlorothiazide at $272.0 \mathrm{~nm}$

- Prepration of Calibration Curve of Candesartan and Hydrochlorothiazide

\section{Prepration of Calibration Curve of Candesartan}

Accurately weighed $10 \mathrm{mg}$ of pure Candesartan was dissolved in $2.0 \mathrm{ml}$ of methanol and volume make upto 10 $\mathrm{ml}$ with $6.8 \mathrm{pH}$ buffer solution in $10 \mathrm{ml}$ of volumetric flask and prepare suitable dilution to make it to a concentration of $1000 \mu \mathrm{g} / \mathrm{ml}$ make adequate of sample with concentration range of $5-25 \mu \mathrm{g} / \mathrm{ml}$ with with $6.8 \mathrm{pH}$ buffer solution. The spectrum of this solution was run in $200-400 \mathrm{~nm}$ range in U.V spectrophotometer.

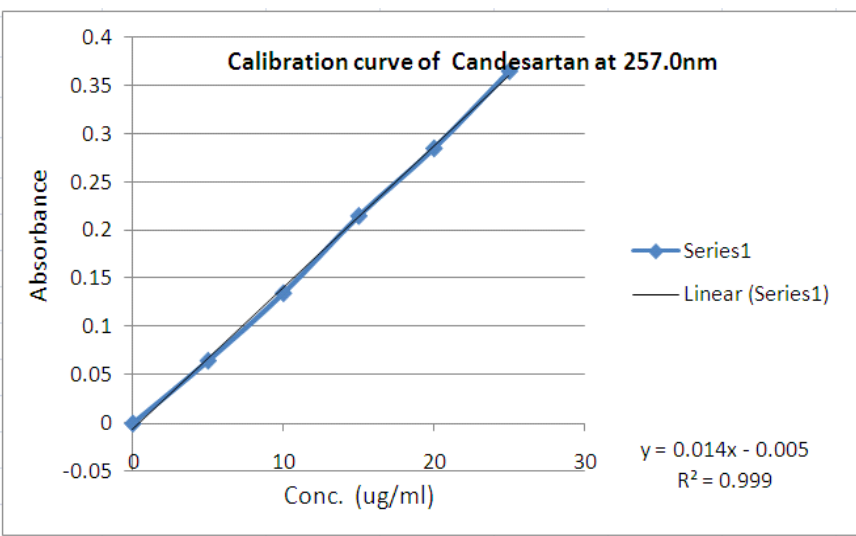

Figure 9: Standard Calibration Curve of Candesartan

Regression Equation

$\mathrm{Y}=\mathrm{mx}+\mathrm{c}$,

$\mathrm{Y}=\quad \mathrm{AUC}$

$\mathrm{m}=\quad$ slope $=0.014$

$\mathrm{X}=\quad$ Conc. in $\mathrm{g} / \mathrm{ml}$

$\mathrm{c}=\quad$ Intercept $=0.005$

$\mathrm{r}^{2}=0.999$

- Prepration of Calibration Curve of Hydrochlorothiazide

Accurately weighed $10 \mathrm{mg}$ of pure Hydrochlorothiazide was dissolved in $2.0 \mathrm{ml}$ of methanol and volume make upto $10 \mathrm{ml}$ with $6.8 \mathrm{pH}$ buffer solution in $10 \mathrm{ml}$ of volumetric flask and prepare suitable dilution to make it to a concentration of $1000 \mu \mathrm{g} / \mathrm{ml}$ make adequate of sample with concentration range of $5-25 \mu \mathrm{g} / \mathrm{ml}$ with with $6.8 \mathrm{pH}$ buffer solution. The spectrum of this solution was run in 200-400 $\mathrm{nm}$ range in U.V spectrophotometer.

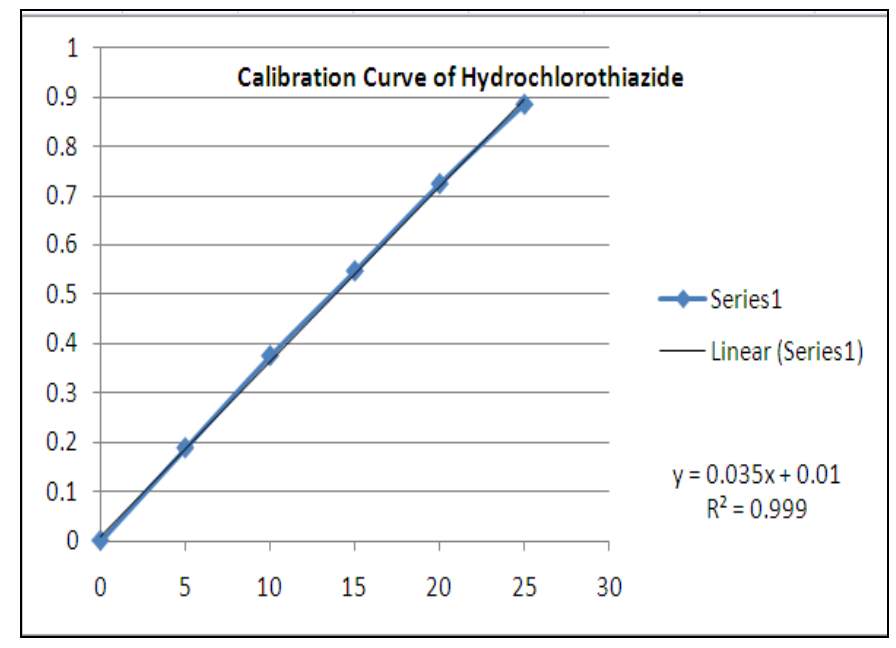

Figure 10: Standard Calibration Curve of Hydrochlorothiazide

Regression Equation

$\begin{array}{ll}\mathrm{Y}= & \mathrm{mx}+\mathrm{c}, \\ \mathrm{Y}= & \text { AUC } \\ \mathrm{m}= & \text { slope }=0.032 \\ \mathrm{X}= & \text { Conc. } \text { in } \mathrm{g} / \mathrm{ml} \\ \mathrm{c}= & \text { Intercept }=0.027 \\ \mathrm{r}^{2}=0.995\end{array}$


- Optical parameters of Candesartan and Hydrochlorothiazide

Table 10: Result of Optical Parameter of Candesarta and Hydrochlorothiazide

\begin{tabular}{|c|c|c|c|}
\hline S. No. & Parameters & Observation Candesartan & Observation Hydrochlorothiazide \\
\hline 1 & $\lambda_{\max }$ & $257.0 \mathrm{~nm}$ & 272.0 \\
\hline 2 & Beer's law limit $(\mu \mathrm{g} / \mathrm{mL})$ & $5-25 \mu \mathrm{g} / \mathrm{ml}$ & $5-25 \mu \mathrm{g} / \mathrm{ml}$ \\
\hline 3 & Regression equation & $\mathrm{Y}=0.014 \mathrm{x}-0.005$ & $\mathrm{Y}=0.035 \mathrm{x}+0.010$ \\
\hline 4 & Correlation Coefficient $\left(\mathrm{r}^{2}\right)$ & 0.999 & 0.999 \\
\hline
\end{tabular}

\subsubsection{COMPATIBILITY STUDIES OF DRUG AND EXCIPIENTS}

In the compatibility testing program, blends of drug and excipients are prepared by triturating the drug with Individual excipients.

Procedure: Take $50 \mathrm{mg}$ accurately weigh of drug dry powder and $50 \mathrm{mg}$ of excipients and mix the blend of drug and excipients and binary/tertiary blends of extract and excipients were prepared and transferred to inert glass vials. The mouths of the vials were covered with rubber closures followed by the aluminum seal caps. Binary/tertiary blends of extract and excipients, drug neat and excipients were stored at $4^{\circ} \mathrm{C}$ (refrigerator) as control; and at $40^{\circ} \mathrm{C} / 75 \% \mathrm{RH}$ for accelerated stability studies for 4 weeks. The visual observations (color, flow, \& sticking) were recorded for initial and at the end of the first, second, third and fourth week.

\subsection{PHASE I- PREPRATION OF INSTANT LAYER OF HYDROCHLOROTHIAZIDE}

\subsubsection{Evaluation of Pre-compression Parameters:}

Blend ready for compression containing drug and various excipients was subjected for pre-compression parameters to study the flow properties of granules, to achieve uniformity of tablet weight.

\section{A) Angle of repose ( $\theta)$ :}

The data obtained for angle of repose for all the formulations were tabulated in Table No.7.8. The values were found to be in the range of $34^{\circ}$, to $41^{\circ}$. All the formulations prepared showed the angle of repose less than $41^{\circ}$, which reveals passable flow property.

\section{B) Loose Bulk Density and Tapped Bulk Density:}

Loose bulk density (LBD) and tapped bulk density (TBD) for the blend is shown in Table No.7.8 The loose bulk density and tapped bulk density for all the formulation blend varied from $0.33 \mathrm{gm} / \mathrm{cm}^{3}$ to $0.34 \mathrm{gm} / \mathrm{cm}^{3}$ and 0.50 $\mathrm{gm} / \mathrm{cm}^{3}$ to $0.53 \mathrm{gm} / \mathrm{cm}^{3}$ respectively.

\section{C) Carr's compressibility index and Hausner's ratio:}

The results of Carr's consolidation index or compressibility index $(\%)$ for the entire formulation blend ranged from 28.30 to 40.38 . The directly compressible granulations had shown excellent compressibility index values which results in Poor flow properties.

The results of Hausner's ratio for all the formulation blend is less than 0.570 , which shows good flow property.

Table 11: Pre-Compression Parameters of Hydrochlorothiazide

\begin{tabular}{|c|c|c|c|c|c|}
\hline \multirow[b]{2}{*}{$\begin{array}{l}\text { Formulation } \\
\text { code }\end{array}$} & \multicolumn{5}{|c|}{ Parameters } \\
\hline & $\begin{array}{c}\text { Loose Bulk } \\
\operatorname{density}(\mathrm{gm} / \mathrm{ml})\end{array}$ & $\begin{array}{c}\text { Tapped bulk } \\
\operatorname{density}(\mathrm{gm} / \mathrm{ml})\end{array}$ & $\begin{array}{c}\text { Carr's Index } \\
(\%)\end{array}$ & $\begin{array}{l}\text { Hausner's } \\
\text { Ratio }\end{array}$ & $\begin{array}{l}\text { Angle of } \\
\text { Repose }\end{array}$ \\
\hline TM1 & 0.33 & 0.50 & 34.00 & 1.515 & $37^{\circ}$ \\
\hline TM2 & 0.32 & 0.51 & 37.25 & 1.594 & $38^{\circ}$ \\
\hline TM3 & 0.31 & 0.52 & 40.38 & 1.677 & $34^{\circ}$ \\
\hline TM4 & 0.33 & 0.53 & 37.74 & 1.606 & $40^{\circ}$ \\
\hline TM5 & 0.30 & 0.50 & 40.00 & 1.667 & $38^{\circ}$ \\
\hline TM6 & 0.34 & 0.51 & 33.33 & 1.500 & $41^{\circ}$ \\
\hline TM7 & 0.32 & 0.52 & 38.46 & 1.625 & $39^{\circ}$ \\
\hline TM8 & 0.38 & 0.53 & 28.30 & 1.395 & $37^{\circ}$ \\
\hline TM9 & 0.35 & 0.50 & 30.00 & 1.429 & $37^{\circ}$ \\
\hline
\end{tabular}

\subsubsection{Evaluation of Post-compression parameters}

\section{A) Shape and colour of tablets:}

Formulations prepared were randomly picked from each batch examined under lens for shape and in presence of light for colour. Tablets showed flat, circular shape in pinkish colour due to add of Colouring agent.

\section{B) Thickness test}

Thickness of the tablets was measured by dial caliper by picking randomly from all the batches. The results of thickness for tablets were shown in Table No. The mean thickness was $(n=3)$ almost uniform in all the formulations and values ranged from $1.40 \pm 0.10 \mathrm{~mm}$. The standard deviation values indicated that all the formulations were within the range.

\section{C) Weight variation test}

The weight variation test is done to ensure the tablet contains the proper amount of drug. All the tablets passed weight variation test as the average percentage weight 
variation was within the pharmacopoeial limits of $\pm 10 \%$ (Table7.9).

\section{D) Hardness test}

The hardness of all the tablets prepared was maintained within the $2.00 \mathrm{~kg} / \mathrm{cm}^{2}$ to $4.00 \mathrm{~kg} / \mathrm{cm}^{2}$. All the tablets maintained hardness in the range $2.51 \pm 0.71 \mathrm{~kg} / \mathrm{cm}^{2}$ to $3.59 \pm 0.51 \mathrm{~kg} / \mathrm{cm}^{2}$ for formulations were almost uniform.

\section{E) Friability test}

The study results tabulated in Table no.7.9 was found to be well within the approved range $(<1 \%)$ in all designed formulations. The formulations TM- 1 and TM- 8 showed slightly higher than the other. This might be due to excess fines or due to improper granulation, but the values were found to be within the limit. Thus tablets possess good mechanical strength.

\section{F) Uniformity of drug content:}

The content uniformity was performed for all the nine formulations and results are tabulated in Table No.7.9 Three trials from each batch were analyzed spectrophotometrically. The average value and standard deviations of all the formulations were calculated. The drug content in different formulation was highly uniform and in the range of $98.51 \pm 0.75-99.53 \pm 0.42 \%$.The results were within the acceptable range and that indicated uniformity of mixing. The cumulative percentage drug released by each tablet in the in vitro release studies was based on the average drug content present in the tablet.

\section{G) In-vitro disintegration time:}

It was observed that the disintegration time of tablets decreased with increase in the concentration of the superdisintegrants. Based on the disintegration results (Table 7.10), the formulation containing crosspovidone $(7.5 \%)$ showed the fastest disintegration.

Among the different formulations, TM4 was chosen as optimized batch containing croscarmilose sodium (5\%) as superdisintegrant, as it has produced the ODT having least disintegration time of $12.0 \pm 0.21 \mathrm{sec}$.

Table 12: Post-Compressional Parameters of All Formulations-I

\begin{tabular}{|c|c|c|c|c|c|}
\hline $\begin{array}{c}\text { Formulation } \\
\text { code }\end{array}$ & $\begin{array}{c}\text { Hardness } \\
\text { test }\left(\mathrm{kg} / \mathrm{cm}^{2}\right) \\
\pm S D, n=3\end{array}$ & $\begin{array}{c}\text { Friability } \\
(\%) \\
\pm \text { SD, } n=10\end{array}$ & $\begin{array}{c}\text { Weight } \\
\text { variation } \\
(\%) n=10\end{array}$ & $\begin{array}{c}\text { Thickness } \\
\quad(\mathrm{mm}) \\
\pm \mathrm{SD}, \mathrm{n}=5\end{array}$ & $\begin{array}{c}\text { Drug } \\
\text { Content }(\%) \\
\pm \text { SD, } n=3\end{array}$ \\
\hline TM1 & $3.13 \pm 0.21$ & $0.8217 \pm 0.01$ & Passes & $1.42 \pm 0.03$ & $99.41 \pm 0.42$ \\
\hline TM2 & $3.70 \pm 0.30$ & $0.7262 \pm 0.05$ & Passes & $1.45 \pm 0.05$ & $99.77 \pm 0.51$ \\
\hline TM3 & $3.51 \pm 0.50$ & $0.5314 \pm 0.03$ & Passes & $1.41 \pm 0.03$ & $98.53 \pm 0.71$ \\
\hline TM4 & $3.73 \pm 0.29$ & $0.6425 \pm 0.11$ & Passes & $1.40 \pm 0.06$ & $99.41 \pm 0.49$ \\
\hline TM5 & $3.81 \pm 0.51$ & $0.6346 \pm 0.05$ & Passes & $1.44 \pm 0.03$ & $99.33 \pm 0.66$ \\
\hline TM6 & $3.50 \pm 0.40$ & $0.7114 \pm 0.16$ & Passes & $1.46 \pm 0.05$ & $98.51 \pm 0.75$ \\
\hline TM7 & $3.66 \pm 0.29$ & $0.5612 \pm 0.07$ & Passes & $1.40 \pm 0.04$ & $99.57 \pm 0.42$ \\
\hline TM8 & $2.77 \pm 0.71$ & $0.8554 \pm 0.11$ & Passes & $1.43 \pm 0.05$ & $98.33 \pm 0.62$ \\
\hline TM9 & $3.12 \pm 0.42$ & $0.7377 \pm 0.15$ & Passes & $1.42 \pm 0.04$ & $99.65 \pm 0.48$ \\
\hline
\end{tabular}

Table 13: Post-compressional Parameters of All Formulations-II

\begin{tabular}{|c|c|}
\hline Formulation code & In-vitro Disintegration Time(sec.) $(\mathbf{n}=3)$ Mean \pm SD \\
\hline TM1 & $3.48 \pm 0.56$ \\
\hline TM2 & $6.40 \pm 0.71$ \\
\hline TM3 & $5.34 \pm 0.41$ \\
\hline TM4 & $12.00 \pm 0.22$ \\
\hline TM5 & $33.34 \pm 1.23$ \\
\hline TM6 & $1.50 \pm 1.53$ \\
\hline TM7 & $1.54 \pm 0.96$ \\
\hline TM8 & $1.03 \pm 0.69$ \\
\hline TM9 & $32.45 \pm 1.15$ \\
\hline
\end{tabular}

\subsection{PHASE II- PREPRATION OF CANDESARTAN MATRIX TABLET}

Table 14: Result of Pre Compression Properties of Candesartan sustained layer

\begin{tabular}{|c|c|c|c|c|c|}
\hline Material & $\begin{array}{c}\text { Angle of } \\
\text { repose(Degree) }\end{array}$ & $\begin{array}{c}\text { Bulk } \\
\text { density(gm/ml) }\end{array}$ & $\begin{array}{c}\text { Tapped } \\
\text { density(gm/ml) }\end{array}$ & $\begin{array}{c}\text { Compressibility } \\
\text { index }\end{array}$ & Hausner ratio \\
\hline F1 & 36 & 0.38 & 0.52 & 26.92 & 1.37 \\
\hline F2 & 33 & 0.37 & 0.50 & 26.00 & 1.35 \\
\hline F3 & 37 & 0.35 & 0.51 & 31.37 & 1.46 \\
\hline F4 & 38 & 0.39 & 0.53 & 26.42 & 1.36 \\
\hline F5 & 35 & 0.38 & 0.52 & 26.92 & 1.37 \\
\hline F6 & 34 & 0.39 & 0.53 & 26.42 & 1.36 \\
\hline F7 & 34 & 0.40 & 0.52 & 23.08 & 1.30 \\
\hline F8 & 38 & 0.38 & 0.51 & 25.49 & 1.34 \\
\hline
\end{tabular}


Table 15: Results of Post Compression Properties of Candesartan sustained layer

\begin{tabular}{|c|c|c|c|c|c|}
\hline Formulation code & $\begin{array}{c}\text { Thickness } \\
(\mathbf{m m})\end{array}$ & $\begin{array}{c}\text { Hardness } \\
\mathbf{( k g / \mathbf { c m } )}\end{array}$ & $\begin{array}{c}\text { Weight } \\
\text { variation }\end{array}$ & $\begin{array}{c}\text { Friability } \\
(\mathbf{\%})\end{array}$ & $\begin{array}{c}\text { Drug content } \\
(\mathbf{\%})\end{array}$ \\
\hline F1 & 3.5 & 6.5 & Passes & 0.83 & 99.12 \\
\hline F2 & 3.7 & 6.4 & Passes & 0.67 & 99.25 \\
\hline F3 & 3.5 & 6.3 & Passes & 0.66 & 99.23 \\
\hline F4 & 3.6 & 6.4 & Passes & 0.78 & 99.21 \\
\hline F5 & 3.6 & 6.5 & Passes & 066 & 99.10 \\
\hline F6 & 3.4 & 6.2 & Passes & 0.89 & 99.56 \\
\hline F7 & 3.5 & 6.3 & Passes & 0.74 & 99.89 \\
\hline F8 & 3.4 & 6.5 & Passes & 0.99 & 99.54 \\
\hline F9 & 3.6 & 6.2 & passes & 0.89 & 99.26 \\
\hline
\end{tabular}

\section{RELEASE KINETICS OF CANDESARTAN MATRIX TABLET}

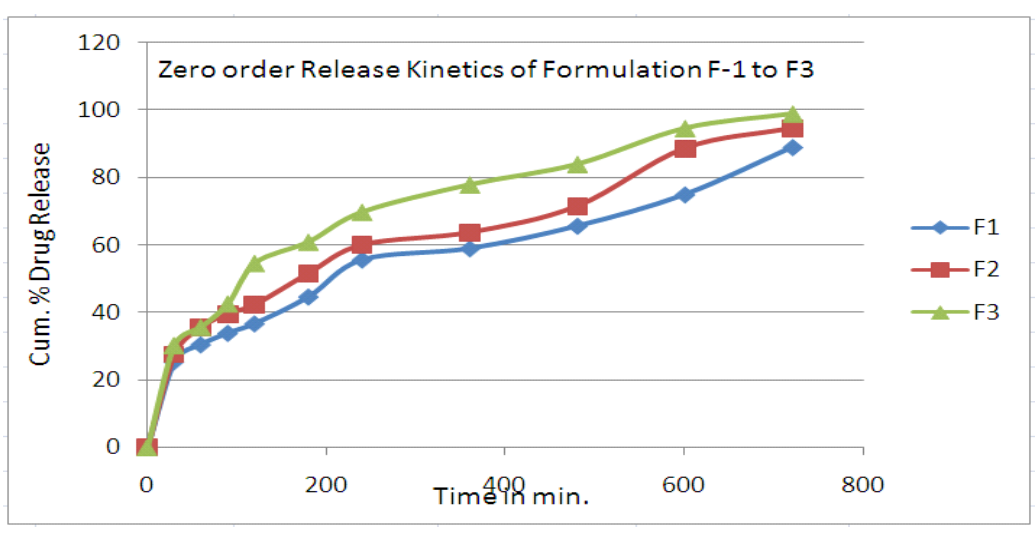

Figure: 11: Zero order release kinetics data Candesartan Matrix tablet with HPMC K-4 as Binder

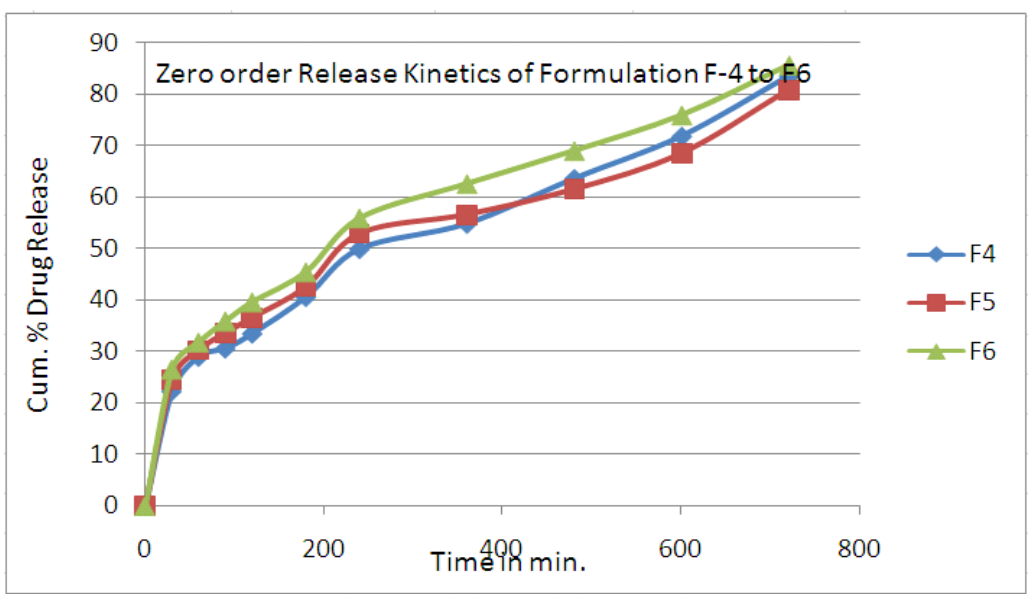

Figure 12: Zero order release kinetics data Candesartan Matrix tablet with HPMC K-15 as Binder

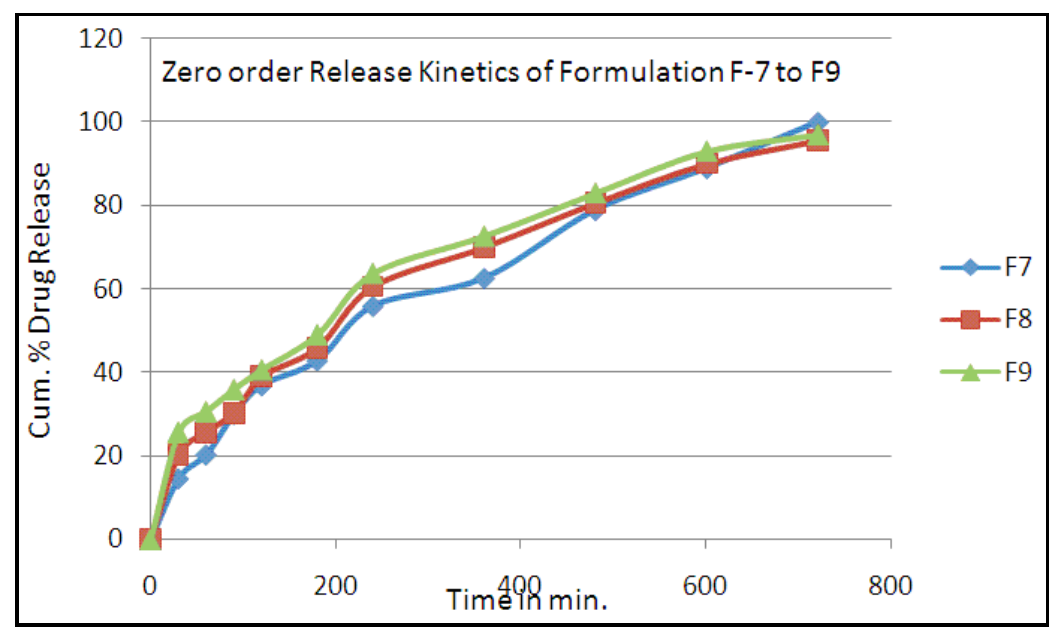

Figure 13: Zero order release kinetics data Candesartan Matrix tablet with HPMC K-4+ HPMC K-15 as Binder 


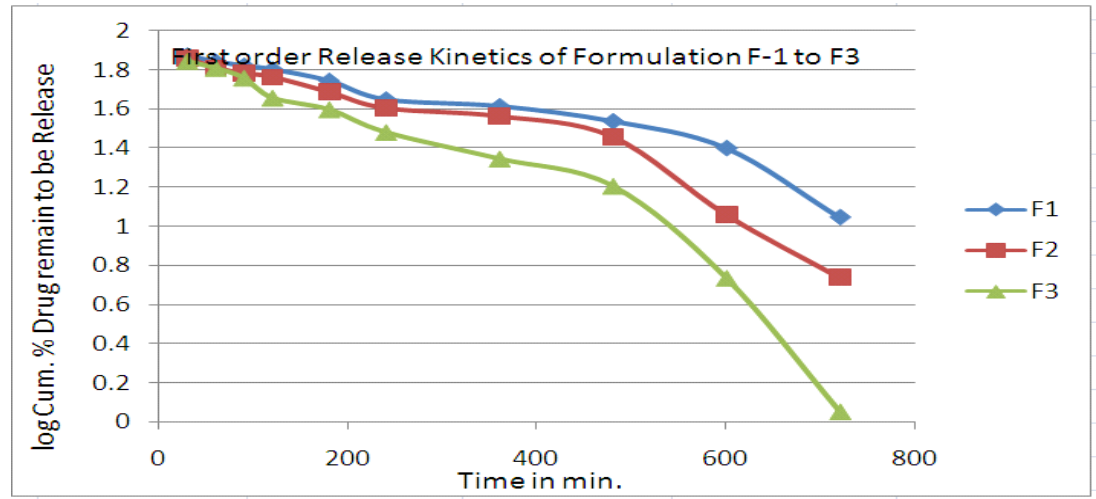

Figure 14: First order release kinetics data Candesartan Matrix tablet with HPMC K-4 as Binder

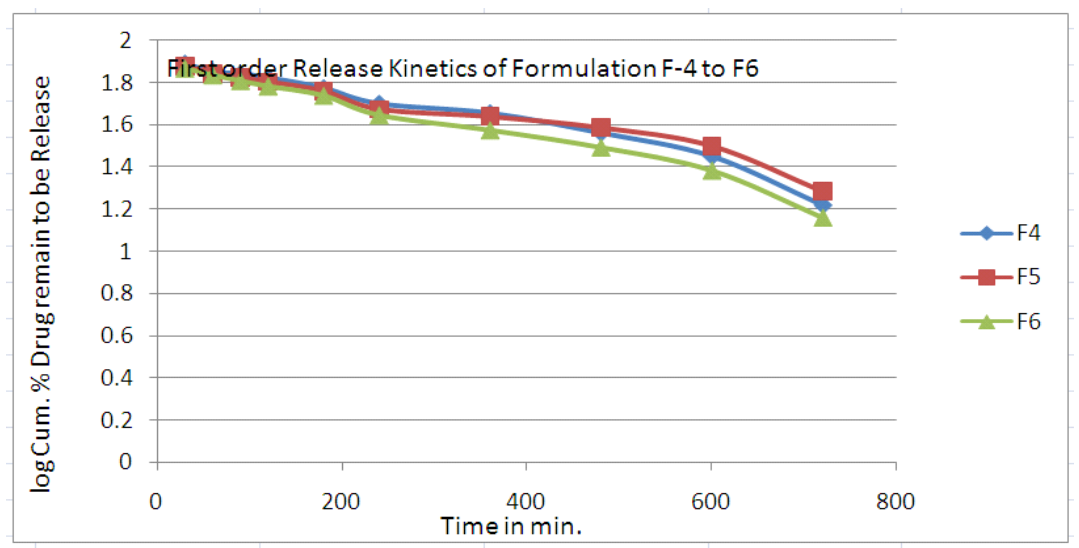

Figure no 15: First order release kinetics data Candesartan Matrix tablet with HPMC K-15 as Binder

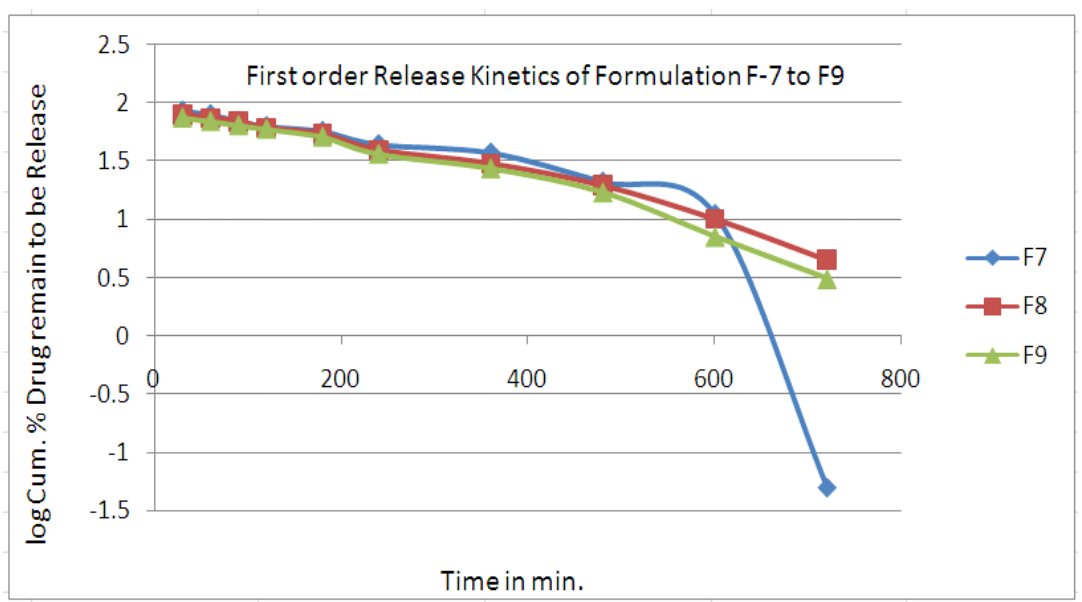

Figure 16: First order release kinetics data Candesartan Matrix tablet with HPMC K-4 + HPMC K-15 as Binder

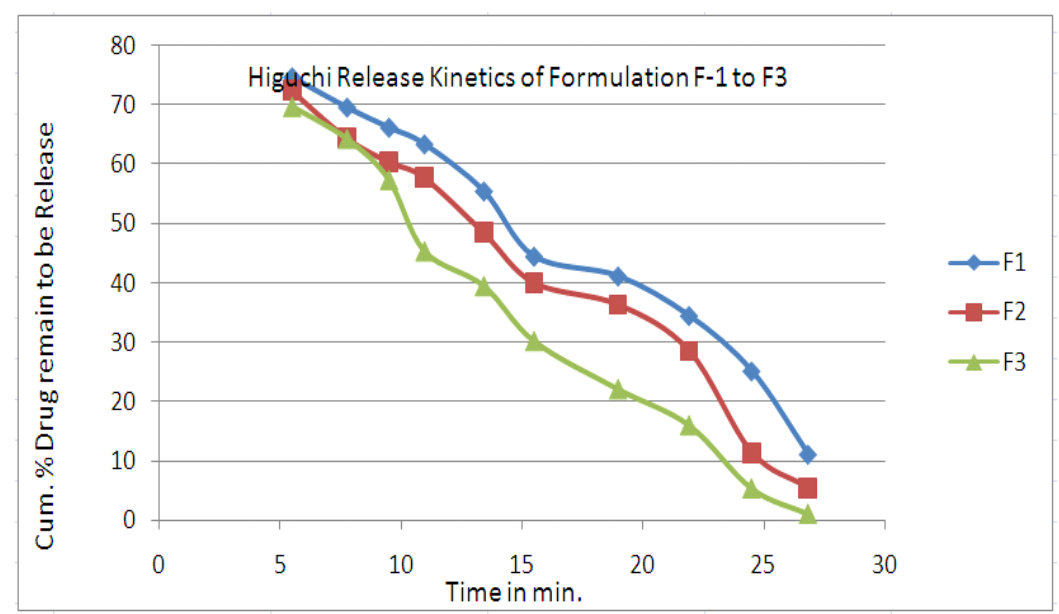

Figure 17: Higuchi release kinetics data Candesartan Matrix tablet with HPMC K-4 as Binder 


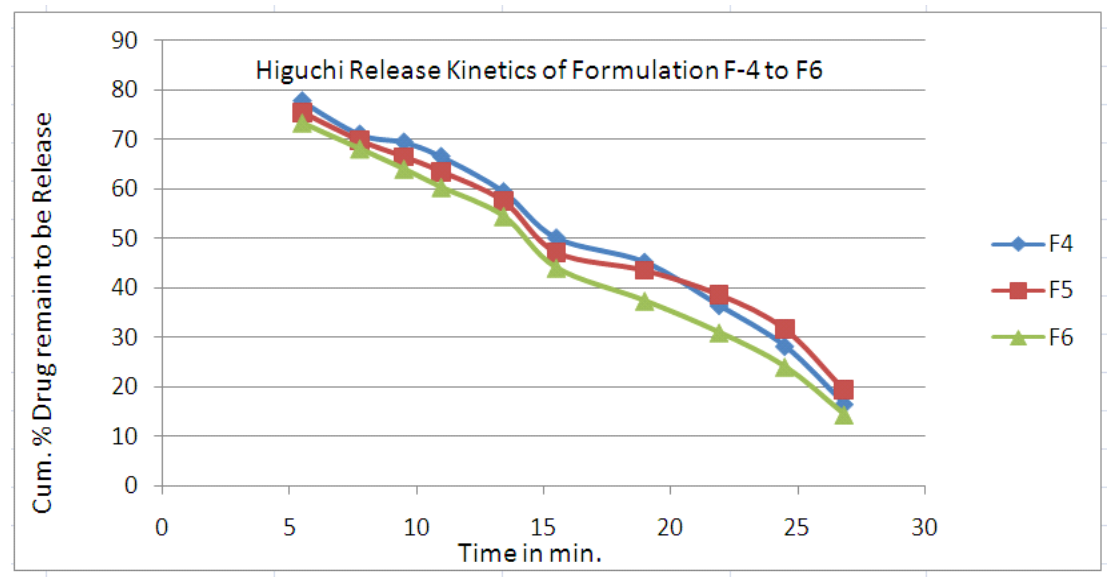

Figure 18: Higuchi release kinetics data Candesartan Matrix tablet with HPMC K-15 as Binder

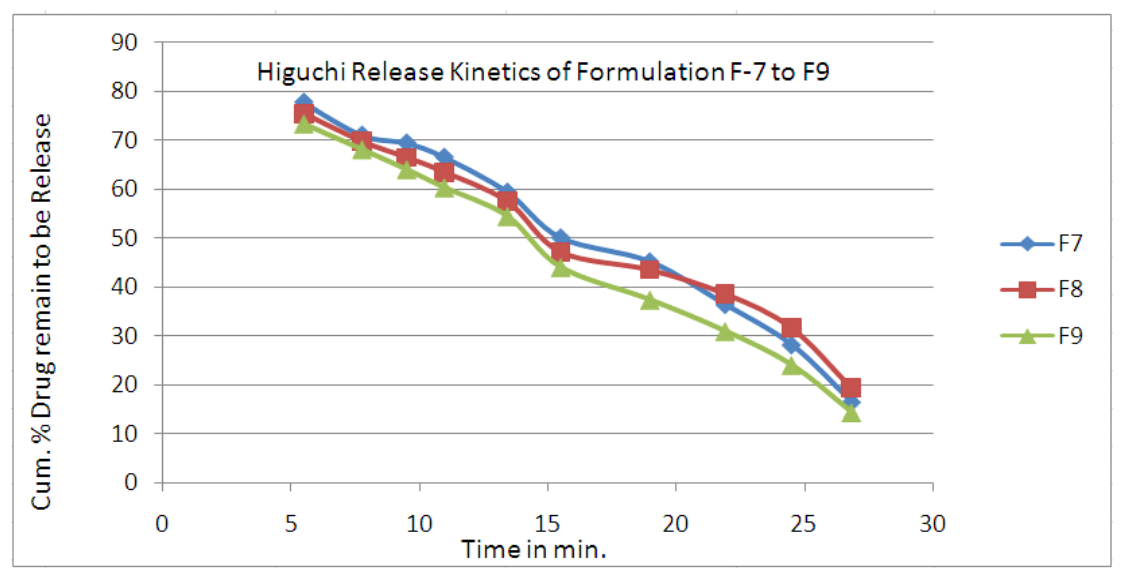

Figure 19: Higuchi release kinetics data Candesartan Matrix tablet with HPMC K4 + K-15 as Binder

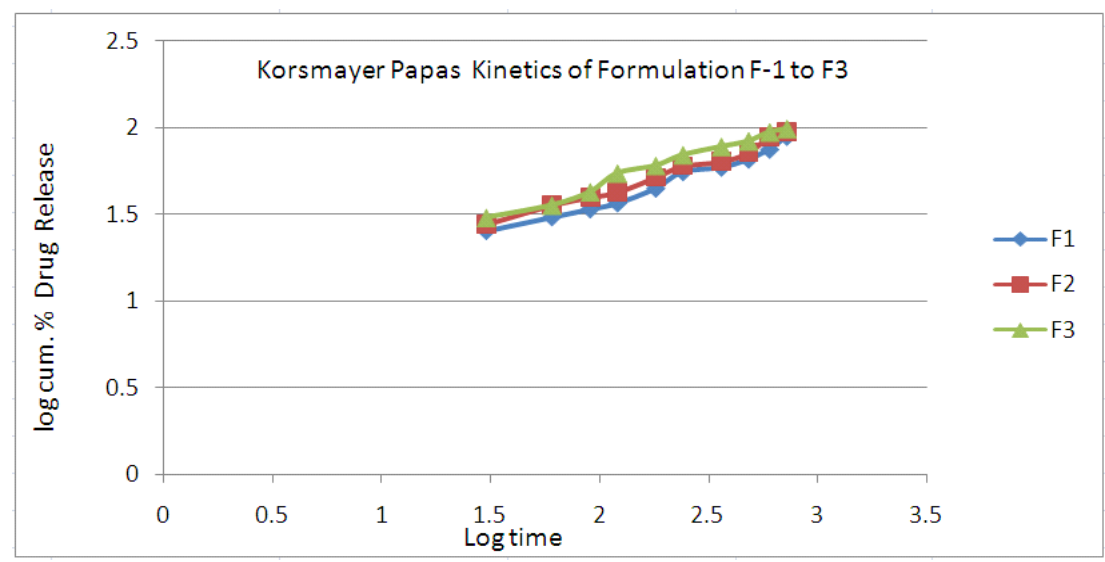

Figure 20: Korsmayer Papas release kinetics data Candesartan Matrix tablet with HPMC K4 as Binder

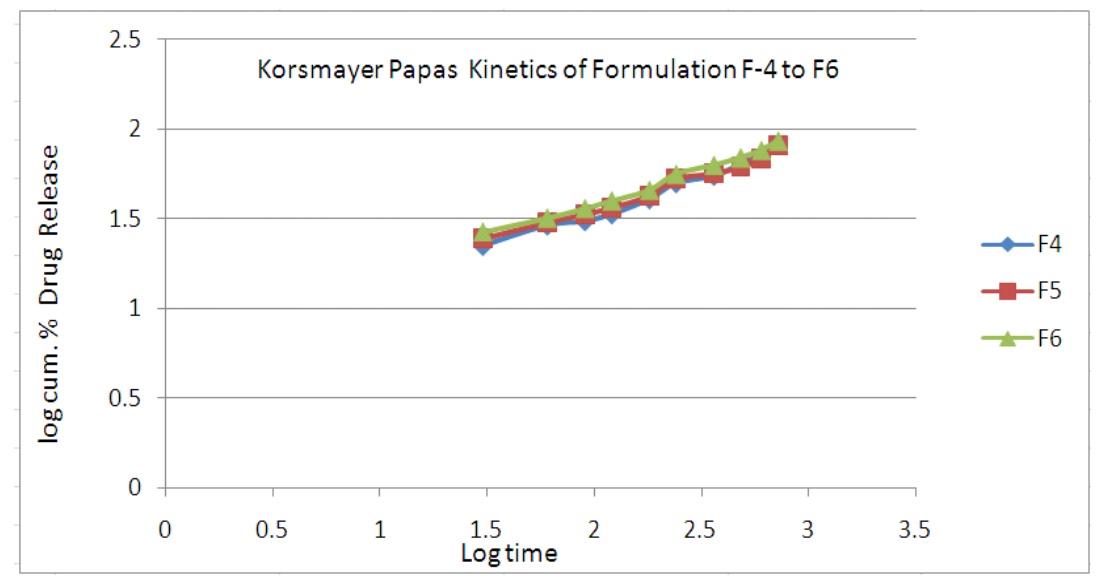

Figure 21: Korsmayer Papas release kinetics data Candesartan Matrix tablet with HPMC K-15 as Binder 


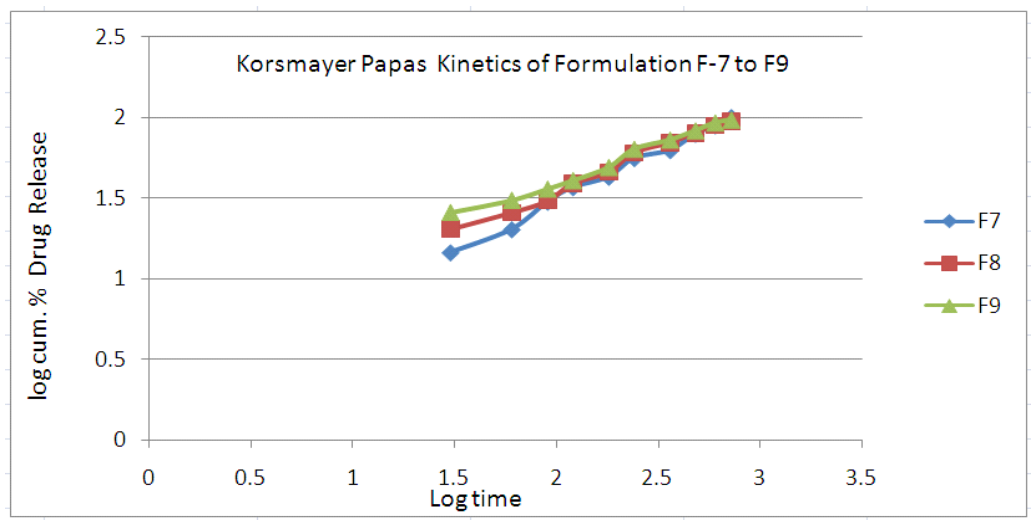

Figure 22: Korsmayer Papas release kinetics data Candesartan Matrix tablet with HPMC K4 + K-15 as Binder

Table 16: Kinetic data of Candesartan Matrix Tablet in comparison with All Formulation

\begin{tabular}{|c|c|c|c|c|c|}
\hline FORMULATION & $\begin{array}{l}\text { REGRATION } \\
\text { COEFFICIENT }\end{array}$ & $\begin{array}{l}\text { ZERO } \\
\text { ORDER }\end{array}$ & $\begin{array}{l}\text { FIRST } \\
\text { ORDER }\end{array}$ & HIGUCHI & $\begin{array}{l}\text { KORSMAYER } \\
\text { PAPAS }\end{array}$ \\
\hline F1 & $\mathrm{r}^{2}$ & 0.891 & 0.924 & 0.978 & 0.975 \\
\hline F2 & $\mathrm{r}^{2}$ & 0.881 & 0.920 & 0.981 & 0.983 \\
\hline F3 & $\mathrm{r}^{2}$ & 0.848 & 0.917 & 0.982 & 0.986 \\
\hline F4 & $\mathrm{r}^{2}$ & 0.910 & 0.965 & 0.986 & 0.999 \\
\hline F5 & $\mathrm{r}^{2}$ & 0.862 & 0.959 & 0.982 & 0.979 \\
\hline F6 & $\mathrm{r}^{2}$ & 0.871 & 0.980 & 0.993 & 0.983 \\
\hline F8 & $\mathrm{r}^{2}$ & 0.951 & 0.673 & 0.986 & 0.999 \\
\hline F9 & $\mathrm{r}^{2}$ & 0.920 & 0.974 & 0.982 & 0.992 \\
\hline & $\mathrm{r}^{2}$ & 0.904 & 0.966 & 0.993 & 0.989 \\
\hline
\end{tabular}

\section{RESULTS OF POST COMPRESSION PROPERTIES OF BILAYER TABLETS}

Table 17: Results of post compression property of bilayer tablets

\begin{tabular}{|c|c|c|c|c|c|}
\hline $\begin{array}{l}\text { Formulation } \\
\text { code }\end{array}$ & $\begin{array}{l}\text { Hardness test } \\
\left(\mathrm{kg} / \mathrm{cm}^{2}\right) \\
\pm \mathrm{SD}, \mathrm{n}=3\end{array}$ & $\begin{array}{l}\text { Friability } \\
(\%) \\
\pm \text { SD, } n=10\end{array}$ & $\begin{array}{l}\text { Weight } \\
\text { variation } \\
(\%) n=10\end{array}$ & $\begin{array}{l}\text { Thickness } \\
(\mathrm{mm}) \\
\pm \mathrm{SD}, \mathrm{n}=5\end{array}$ & $\begin{array}{l}\text { Drug Content } \\
(\%) \\
\pm \text { SD, } n=3\end{array}$ \\
\hline TM1 & $7.12 \pm 0.21$ & $0.8217 \pm 0.01$ & Passes & $6.00 \pm 0.03$ & $99.53 \pm 0.42$ \\
\hline TM2 & $7.70 \pm 0.30$ & $0.7262 \pm 0.05$ & Passes & $6.01 \pm 0.05$ & $99.41 \pm 0.51$ \\
\hline TM3 & $7.51 \pm 0.50$ & $0.5314 \pm 0.03$ & Passes & $6.01 \pm 0.03$ & $98.77 \pm 0.71$ \\
\hline TM4 & $7.73 \pm 0.29$ & $0.6425 \pm 0.11$ & Passes & $6.00 \pm 0.06$ & $99.12 \pm 0.49$ \\
\hline TM5 & $7.81 \pm 0.51$ & $0.6346 \pm 0.05$ & Passes & $6.01 \pm 0.03$ & $99.33 \pm 0.66$ \\
\hline TM6 & $7.50 \pm 0.40$ & $0.7114 \pm 0.16$ & Passes & $6.01 \pm 0.05$ & $98.51 \pm 0.75$ \\
\hline TM7 & $7.66 \pm 0.29$ & $0.5612 \pm 0.07$ & Passes & $6.01 \pm 0.04$ & $99.65 \pm 0.42$ \\
\hline TM8 & $7.77 \pm 0.71$ & $0.8554 \pm 0.11$ & Passes & $4.54 \pm 0.05$ & $98.80 \pm 0.62$ \\
\hline TM9 & $7.12 \pm 0.42$ & $0.7377 \pm 0.15$ & Passes & $4.56 \pm 0.04$ & $99.27 \pm 0.48$ \\
\hline
\end{tabular}

In vitro drug release study of Bi-layered Tablet of Optimized Formulation

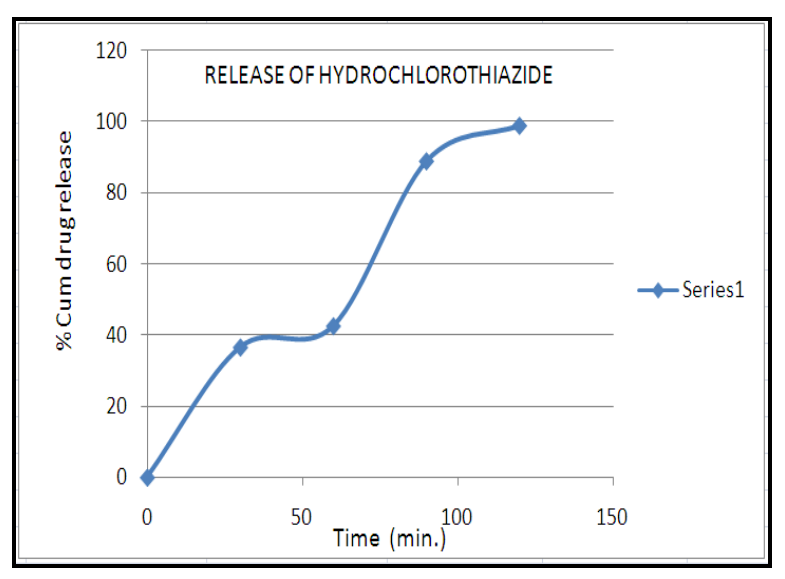

Figure 23: release of Hydrochlorothiazide
In vitro Drug release study of Optimized Formulation No. TM-4 of Instant layer and optimized formulation No. F-7of Matrix layer.

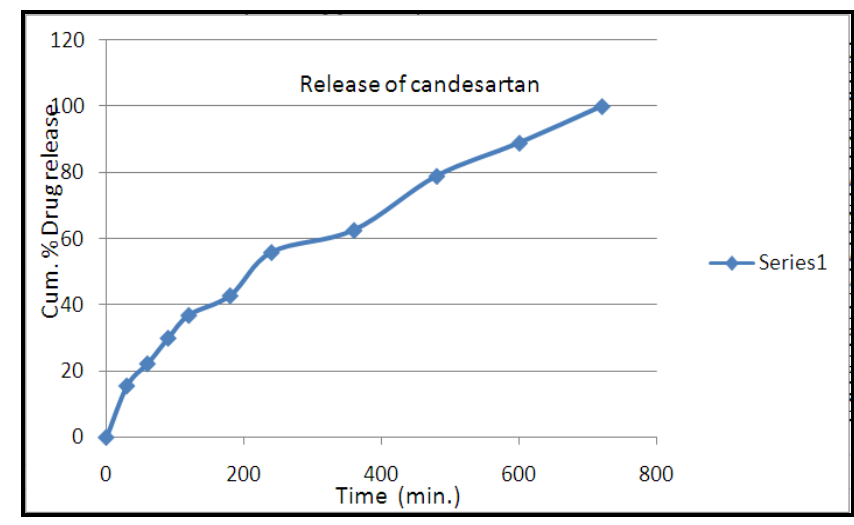

Figure 24: release of Candesartan 
In the present study seven formulations with variable conc entration of polymers (HPMC K-4 and K-15) prepared by direct compression method and evaluated for physiochemical properties, buoyancy lag time ad invitro drug release. The results indicated that optimized the gastric fluid, formulation F7 of matrix tablet and TM4 formulation of instant release on immersion in $0.1 \mathrm{~N}$ $\mathrm{HCl}$ solution for 2 hour and then at $\mathrm{pH} 6.8$ phosphate buffer at $37 \pm 0.5^{\circ} \mathrm{C}$ tablets immediately and remain buoyant upto $12 \mathrm{hrs}$ without disintegration.

These two factors are essential for the tablet to acquire bul $\mathrm{k}$ density $<1$, so that it remains buoyant on The In vitro drug release data of the optimized formulation was subjected to goodness of fit test by linear regression analysis according to zero order, first order kinetic equation, Higuchi's and Korsmeyer's models in order to determine the mechanism of drug release. When the regression coefficient values of were compared, it was observed that ' $r$ ' values of first order was maximum i.e 0.999 hence indicating drug release from formulations was found to follow Korsmeyer's models.

\section{REFERENCES}

1. Talukder R, Fassihi R. Gastroretentive DeliverySystems: A Mini Review. Drug DevIndPharm.2004; 30(10): 1019-28.

2. Garg R, Gupta GD. Progress in Controlled Gastroretentive Delivery Systems. Trop JPharm Res. 2008, Sep; 7(3): 1055-66

3. Patil JM, Hirlekar RS, Gide PS, Kadam VJ. Trends in floating drug delivery systems. JSciInd Res. 2006 Jan; 65:11-21

4. Shaha SH, Patel JK, Pundarik akshudu K, Patel NV.An Overview of a gastro- retentive floating drug delivery system. Asian Journalof Pharmaceutical Sciences. 2009 Jan; 4(1): 65-80

5 http://www.pharmainfo.net/pharma-

6. Arora S, Ali J, Ahuja A, Khar RK, Baboota S. Floating Drug DeliverySystems: Areview.AAPSPharmSciTech.2005 Oct 19;6(3): E372-E390

7. Raza JA, Babb JD, Movahed A. Optimal managementof hyperlipidemiain primary prevention of cardiovascular disease. International JournalofCardiology.2004 Dec; 97(3): 355-66

8. Grundy SM. Atherogenic Dyslipidemia Associated with Metabolic Syndrome and Insulin Resistance. Clinical Cornerstone. 2006; 8(1): S21-S27

9. Jain NK. Progress in controlled and Novel Drug Delivery Systems. ${ }^{\text {st }}$ ed Delhi: CBS Publishers andDistributors; 2004. P.7695

10. VyasSP, Khar RK. Controlled drugdeliveryconcepts and advances. 1 st ed. Delhi: M.K.Jain forVallabhPrakashan; 2002. P.196-215

11. Metkar Vishal, Kumar Anuj, Pant Pankaj, Pal Deepti, Sahu Shraddha, Shurngarpure Mansee, Madhusudan Dutta, Formulation development and evaluation of Bilayer tablets ofLornoxicam2012, 4 (2): 173-179

12. Hariprasanna R.C, Qamar Jamal Ahmad, Upendrakulkarni Design and Evaluation Twice Daily Lornoxicam Bi-Layer Matrix Tablets By UsingHydrophilic Polymer Sodium AlginateIssue 2 (Vol. 1) 2011

13. Prabhakar Shirse, Formulation and Evaluation of Bilayer Tablets of Diclofrenac Sodium with Ranitidine HCL forSustained and Immediate Release02 (05); 2012: 136-141

\section{CONCLUSION}

Bilayer tablet is improved beneficial technology to overcome the shortcoming of the single layered tablet. There is various application of the bi-layer tablet it consist of monolithic partially coated or multilayered matrices. Bilayer tablet is suitable for sequential release of two drugs in combination, separate two incompatible substances and also for sustained release tablet in which one layer is immediate release as initial dose and second layer is maintenance dose. The preparation of tablets in the form of multi layers is used to provide systems for the administration of drugs, which are incompatible and to provide controlled release tablet preparations by providing surrounding or multiple swelling layers. Bilayer tablet quality and GMP-requirements can vary widely. Bilayer tablets offer an excellent opportunity for manufacturers to separate themselves from their competitors, improve their products' efficacy, and protect against impersonator products.

14. Hosna Banu, Mostafa Reaj Sahariar, Muhammad Shahdaat Bin Sayeed, Irin Dewan and S.M. Ashraful Islam Formulation development of bi-layer acetaminophen tablets forextended drug release2011, 3(6):348-360

15.Sachin Gowardipe, K. Jaganathan, R. Sambath Kumar, P. Peruma formulation and In Vitro Evaluation of Lamivudine Andzidovudine Controlled Release Bilayer Matrix Tabletvol 3 Issue 1 (Jan-Mar) - 2012s

16. Durga Prasad Pattanayak* and Subash C. DindaBilayer tablet formulation of metformin hydrochloride and glimepiride: A novel approach to improve therapeutic efficacy, 1(1): Jan-Mar: (2011), $1-4$

17. Sharif et al, Design and Evaluation of Modified ReleaseBilayer Tablets of Flurbiprofen2011, 20, 3, 343-349

18. Shirse P. Formulation and Evaluation of Bilayered Tablets of hydrochloride For Immediate And Sustain Release2012 July; 3(3): (P) $148-160$

19. Karwa P, Kasture PV, Formulation and in vitro evaluation of BilayerTablets of Zolpidem tartrate for Biphasic DrugReleaseVol.3, No.4, pp 1919-1929, Oct-Dec 2011

20. Chinam Niranjan Patra, Arethi Bharani, Kumar hemant, Kumar Pandit, Satya Prakash Singh, Meduri Vimala Devi, Design And Evaluation of Sustained Release Bilayer Tabletsof Propranolol Hydrochloride57 (2007) 479-489

21. MANaeem. A Mahmood, SA Khan and Z Shahiq Development and Evaluation of Controlled-ReleaseBilayer Tablets Containing MicroencapsulatedTramadol and Acetaminophen2010; 9 (4): 347354

22. Muthukumaran1 M, Dhachinamoorthi D, Chandra Sekhar KB, Fabrication and evaluation of sustained release mucoadhesive bilayer tabletscontaining nifedipine2012, 3 (3):367-376

23. Swamy PV. Kinagi MB, Biradar S. S., Gada S. N. and ShilpaHFormulation Design and Evaluation of Bilayer Buccal Tablets ofGranisetron Hydrochloride2011/ Vol 45/ Issue 3

24. Ali Sharif1, Mahboob E-Rabbani2, Muhammad Furqan Akhtar1, Bushra Akhtar2,Ammara Saleem2, Kalsoom Farzana2, Atif Usman2, Ghulam Murtaza3Design and Evaluation of Modified ReleaseBilayer Tablets of Flurbiprofen2011, 20, 3, 343-349 